\title{
SASAK MUSLIMS AND INTERRELIGIOUS HARMONY Ethnographic Study of the Perang Topat Festival in Lombok - Indonesia
}

\author{
Suprapto \\ IAIN Mataram - Indonesia | praptolombok@gmail.com
}

\begin{abstract}
Ample local traditions serve as the catalysts that help build social integration within multicultural society. The social inclusion is developed when people from diverse ethnic and religious groups are deliberate to engage. The perang topat festival is a local tradition in Lombok, Indonesia, which includes two communities from different ethnicities and religions: Balinese-Hindus and SasakMuslims. The festival has been celebrated for years and has contributed significantly to maintaining harmony between various ethno-religious groups. This article is an ethnographic research report of the perang topat festival. The tradition has existed as a symbol of civic engagement between Muslims and Hindus. Nevertheless, Muslim puritans have recently criticized and banned Muslims' participation in the perang topat festival. The Muslim puritans believe that integrating religious rituals with traditions is a bid'ah (heresy). On the other hand, Muslim proponents of perang topat justify it through the construction of symbolic meanings of the festival site, utensils, and rituals in accordance with Islamic concepts.
\end{abstract}

Keywords: Lombok, Perang Topat, Sasak Muslims, Hindu, civic engagement, symbolic meaning, harmony

\section{Introduction}

Contemporary research in peacebuilding and conflict resolution pays considerable attention to practices of the consolidation of peace in society including religious communities. ${ }^{1}$ Harmonious relation

\footnotetext{
1 See Oliver Ramsbotham, Tom Woodhouse and Hugh Mial, Contemporary Conflict Resolution. The Prevention, Management and Transformation of Deadly Conflicts (Cambridge: Polity Press, 2006), p. 10.
} 
between diverse religious communities is significant to study because it is an essential element of the conflict resolution process based on local wisdom and tradition. ${ }^{2}$ Patterns in people's daily relationship and their participation in various communal activities in particular events are important indicators of civic engagement. Within multicultural society, high civic engagement is a fundamental aspect in preventing tension leading to violent conflict. ${ }^{3}$

Mechanisms of conflict prevention and peacebuilding will be sustainable when people are willing to establish two engagements: bonding engagement within a group and bridging engagement between diverse groups. The perang topat tradition embodies bridging engagement between various religious communities in Lombok.

Perang topat or topat fight, a fight using ketupat (rice caked boiled in a rhombus-shaped packet of plaited young coconut leaves), is a religious ritual as well as a cultural event performed by people in Lombok annually. ${ }^{4}$ Although the tradition is termed a "fight," it is not violence and hostility. After several religious ceremonies, the festival participants divide themselves into two groups. The teams come face to face and do a fight enthusiastically by throwing ketupat to each other. When the battle ends, they clean all the ketupat scattered in the temple area. They bring the ketupat home and then spread it in their rice fields and fishponds. They believe that the ketupat brings blessings for soil fertility and abundant harvests. One of the symbolic meanings

\footnotetext{
${ }^{2}$ Many scholars have started to publish their work, especially on the tradition of peace among the Muslim community. See, for example, Ralph H. Salmi, Cesar Adib Majul, George Kilpatrick Tanham, Islam and Conflict Resolution: Theories and Practices (Lanham: University Press of America, 1998); Abdul Aziz Said, Nathan C. Funk, Ayse S. Kadayifci, Peace and Conflict Resolution in Islam: Precept and Practice (Lanham: University Press of America, 2001); Mohammed Abu Nimer, Non Violence and Peace Building in Islam: Theory and Practice (Florida: University Press of Florida, 2003).

3 Ashutosh Varshney, Ethnic Conflict and Civic Life: Hindus and Muslims in India (New Haven and London: Yale University Press, 2002), p. 11. See also Suprapto, Semerbak Dupa di Pulau Seribu Masjid (Jakarta: Prenada Kencana, 2013), p. 41.

${ }^{4}$ See Suprapto, "Taqālīd 'Ḥarb’ Topat: Ramz al-'Alāqah al-Silmīyah bayn al-Jamā 'āt alMukhtalifah 'Ariqīyā wa-Dīnīyā fị Jazīrat Lombok," Studia Islamika 18, no. 3 (2014); I Wayan Wirata, "Inter-cultural Communication between Local Hindu and Islamic Community in Perang Topat Ceremony in Lingsar Temple, Narmada District, Lombok," History 5, no. 13 (2015): pp. 7-10; Erni Budiwanti, "Balinese Minority Versus Sasak Majority: Managing Ethno-Religious Diversity and Disputes in Western Lombok," Heritage of Nusantara: International Journal of Religious Literature and Heritage 3, no. 2 (2015), pp. 233-250.
} 
of perang topat is that humans have to fight against their evil desires and be grateful for all blessings from One Almighty God.

In an ethnographic study, analyzing and interpreting symbolic meanings of a tradition are essential to understanding a culture of society more deeply. Humans are makers of meanings. ${ }^{5}$ Almost all people' words, attitudes, and behaviors are related to various symbols. This fact has encouraged anthropologists like Geertz ${ }^{6}$ and Turner ${ }^{7}$ to focus their studies on finding meanings of religious and cultural symbols. ${ }^{8}$

In this article, the perang topat ceremony in Lingsar and its symbolic meanings are analyzed. The analysis includes the history of Kemalik and Lingsar Temple as well as the meanings of the water fountain and various utensils used in the perang topat festival. Traditional Muslim leaders have constructed and presented symbolic meanings of perang topat to public to substantiate it as a tradition that conforms to Islamic theology. Besides, they have provided a rational explanation of perang topat to build a harmonious relation among diverse religious communities. In other words, such efforts made by the traditional Muslim leaders play a significant role in preserving perang topat as a perennial cultural heritage, educating Sasak Muslims in Lombok, and maintaining harmony with Hindus. Harmony between two different ethno-religious groups, Balinese-Hindus and Sasak-Muslims, is evident in this feast. ${ }^{9}$

\footnotetext{
${ }^{5}$ Max Weber calls humans as "meaning makers". This concept is fundamental because it associated with the creation of humans to understand the natural environment and social order. For further explanation see, Fiona Bowie, The Anthropology of Religion: an Introduction (Massachusetts: Blackwell Publisher, 2001), p. 38.

${ }^{6}$ Clifford Geertz, Local Knowledge: Further Essays in Interpretative Anthropology (New York: Basic Books, 1983), p. 119. For comparison and critique of Geertz's thesis, see Bambang Pranowo, Memahami Islam Jawa (Jakarta: Pustaka Alvabet, 2011).

7 Turner, as cited by Irwan Abdullah, calls it as a "processual symbolic", which is a study of how symbols mobilize social action and through the process of how the symbols acquire and give meaning to the community and the person. Irwan Abdullah, Simbol, Makna dan Pandangan Hidup Jawa: Analisis Gunungan pada Upacara Grebeg (Yogyakarta: Balai Kajian Sejarah dan Nilai Tradisional, 2002), p. 13.

8 The main paradigm in understanding culture is interpretative symbolic paradigm. The approach is a hermeneutic approach. This paradigm has been developed by a number of scholars such as Ludwig Witgestein, Hans-Georg Gadamaer, Martin Heideger, Paul Ricoeur, and Jurgen Habermas. See Ahmad Fedyani Saifuddin, Antropologi Kontemporer: Suatu Pengantar Kritis Mengenai Paradigma (Jakarta: Kencana, 2006), pp. 296-300.

9 David D. Harnish, Bridges to The Ancestors: Music, Myth, and Cultural Politics at an Indonesian Festival (Hawaii: University of Hawaii Press, 2006), p. 5; David D. Harnish,
} 
A study of harmony and peacebuilding between diverse religious communities is essential nowadays given that the interreligious relationship in Indonesia has suffered from conflicts. Recently, several ethno-religious conflicts have threatened prevailing peaceful situation..$^{10}$ The study of traditional values in perang topat Lombok will remind people that Indonesian society is more oriented towards harmony and integration than to conflict and disintegration. It should be noted that the processes of social inclusion and cohesion would be jeopardized when some parties enforce their understanding and interpretation of several symbols employed in the perang topat tradition. A preview of socio-culture of the Lingsar community and Muslims in Lombok presented in the following section is fundamental for understanding the perang topat tradition.

\section{The Socio-Cultural Context of Lingsar - Lombok}

Lingsar is a village in West Lombok district, ${ }^{11}$ West Nusa Tenggara Province. Lingsar is easily accessible. Lingsar Temple, where the perang topat tradition takes place, locates in Lingsar village. Lingsar Temple is one of several popular tourist destinations along with Narmada Water Castle and Suranadi ecotourism. Lingsar Temple is a unique site. In the 2.5-hectare area of the temple, visitors can observe worship places used by diverse religious communities, which are Pura (temple) for Hindus and Kemalik for Muslims.

The majority of people in Lingsar work as farmers. Lingsar is one of primary agriculture areas in Lombok Island due to its extensive

\footnotetext{
"Balinese and Sasak Religious Trajectories in Lombok," Between Harmony and Discrimination: Negotiating Religious Identities within Majority-Minority Relationships in Bali and Lombok (Leiden: E.J. Brill, 2014), pp. 61-83. See also Budiwanti, "Balinese Minority Versus Sasak Majority, pp. 233-250.

10 CA. Coppel (ed.), Violent Conflicts in Indonesia: Analysis, Representation, Resolution (London: Routledge, 2005); and Gerry van Klinken, Communal Violence and Democratization in Indonesia: Small Town W ars (London: Routledge, 2007).

11 After the establishment of Lingsar as an independent sub-district in West Lombok, Lingsar village became the capital. Lingsar sub-district consists of 10 villages and 70 kampongs. Lingsar sub-district includes villages of Batu Kumbung, Batu Mekar, Dasan Geria, Duman, Gegerung, Karang Bayan, Langko, Lingsar, Peteluan Indah, and Sigerongan. According to the West Lombok government, the number of the population in Lingsar sub-district is 67245 consisting of 32577 males and 34668 females. http://lombokbaratkab.go.id/ accessed on March 14, 2016.
} 
farming land and soil fertility. ${ }^{12}$ Compared to other regions in Lombok Island such as Central Lombok and the south part of East Lombok, Lingsar soil is considered very fertile because of its abundant water sources. There are also several plantation areas for rambutan, mangosteen, durian, and mangoes. The abundant water in Lingsar enables people to breed freshwater fish farming. They have created fishponds and fish cages along a river running in the village. Lingsar farmers supply rice, fruits, and freshwater fish to people in Mataram and restaurants and hotels in Senggigi Beach, a popular tourist destination in West Lombok.

In the religious aspect, the Sasak ethnic group, the native of Lombok, becomes the largest community in Lingsar in which most of them are Muslims. In the past, many Muslims in Lingsar believed in Wetu Telu, ${ }^{13}$ a kind of Islamic syncretism in Lombok Island. Recently, the number of Wetu Telu adherents has decreased. Most of Wetu Telu adherents live in Bayan North Lombok now. Islamic preaching and propagation conducted by tuan gurus (Muslim leaders) and preachers from many Islamic boarding schools (pesantren) have caused the decline in the number of Wetu Telu adherents. The existence of Nahdatul Wathan, the biggest religious social organization in Lombok, has also contributed to the spread of Waktu Lima Islam to Wetu Telu adherents. ${ }^{14}$ Besides, some lecturers from the State Islamic Institute of Mataram have conducted community service through religious propagation to the Wetu Telu community in Lingsar. As a result, many Wetu Telu adherents have recently practiced Waktu Lima teachings. Many people from the Wetu Telu community also send their children

12 http://lombokbaratkab.go.id/ accessed on March 14, 2016.

13 For further explanation on Wetu Telu, see Tawalinudin Haris, "Masuk dan Berkembangnya Islam di Lombok; Kajian Data Arkeologi dan Sejarah," Jurnal Pemikiran Sosial Ekonomi No: 01, year 1, Feb-Maret 2002. See also Erni Budiwanti, Islam Sasak: Wetu Telu versus Waktu Lima (Yogyakarta: LKiS, 2000). Leena Marjatta Avonius, Reforming Wetu Telu: Islam, Adat, and the Promises of Regionalism in Post-New Order Lombok. (Helsinki: Yliopistopaino, 2004); Sven Cederroth, A Sacred Cloth Religion?: Ceremonies of the Big Feast Among the Wetu Telu Sasak (Lombok, Indonesia) (Copenhagen, Denmark: NIAS Books, 1999).

14 Budiwanti, Islam Sasak; Sven Cederroth, The Spell of The Ancestors and The Power of Mekkah, A Sasak Community on Lombok (Goteborg: Acta Universitatis Gothoburgensis, 1981); Cederroth, A Sacred Cloth Religion?; Kari Telle, "Spirited Places and Ritual Dynamics among Sasak Muslims on Lombok," Anthropological Forum, vol. 19, no. 3 (2009), pp. 289-306. 
to study at the State Islamic Institute of Mataram, which is the center of Waktu Lima Islam.

The number of Wetu Telu Islam adherents has declined, but some of their religious traditions have been maintained until today. Tuan gurus, Muslim leaders in Lombok, have taught Islam while maintaining the existing cultural traditions. Nevertheless, some new Islamic preachers advocating the purification of Islam have proposed criticism against practices that integrate traditions with religious rituals and condemn them as heresy in Islam. The observance of Islamic prayers in Kemalik and the perang topat tradition are considered heresies. Moreover, Muslims involve Hindus in such rituals.

Balinese-Hindus live beside Sasak-Muslims in Lingsar. BalineseHindus are the second largest community in Lingsar and Lombok Island. Balinese-Hindus came to Lombok Island in the early 17th century when the Karangasem Kingdom invaded West Lombok and colonized the whole Lombok Island in 1740 after defeating the Mataram Kingdom. ${ }^{15}$ The Balinese Kingdom exerted its influence in Lombok gradually. The Kingdom attracted the Lombok people's sympathy by allowing them to practicing their religious beliefs. The Muslim community was allowed to perform their prayers in Kemalik. The Hindus King also built Ulon Temple in Kemalik. In the era of King Agung Gede Ngurah Karangasem, who ruled the Mataram Kingdom (the capital city of Nusa Tenggara Barat Province at the moment), two sacred buildings (Kemalik and Ulon Temple) were united in one area of Lingsar Temple. Sasak-Muslims and Balinese Hindus have shared the site as a worship place since then.

\section{The Site, Origin, and Procession of Perang Topat}

Perang topat ${ }^{6}$ takes place in Lingsar Temple. Lingsar Temple is a unique Hindu praying area. Inside the Lingsar Temple area, there are Kemalik (a building sanctified by Sasak-Muslims) and Ulon Temple and Gaduh Temple (buildings consecrated by Balinese-Hindus). Ulon Temple was built in the east part of Lingsar Temple separately from the other buildings; Gaduh Temple is in the north part facing the

\footnotetext{
${ }^{15}$ Budiwanti, Islam Sasak, p. 9.

16 The perang topat ritual is performed every year on the 15th day of the sixth month in the Balinese calendar (Purnama Saseh Kenem), or the seventh month of the Lombok Sasak calendar (approximately November-December).
} 
westerly direction; and Kemalik is in the south part. ${ }^{17}$ The architecture of the buildings is Balinese. Inside Lingsar Temple, there are a beautiful garden, pond, and water fountain.

The origin of perang topat can be traced from pemangku (custodians) and tetua (elders) of Sasak and Hindu traditions in Lingsar Temple. ${ }^{18}$ In the local folklore, it is stated that there was a Muslim preacher named Sumilir from Java coming to Lombok. ${ }^{19}$ Lombok society respected him highly, appointed him as a datu (king), and ascribed a title of Datu Sumilir (Datu Milir) to him.

It is said that after teaching Islam in Lingsar, Datu Milir was deliberate to continue his journey in teaching Islam in other regions. The community and his followers in Lingsar expected him to stay and prevented him from leaving. Nonetheless, Datu Milir resisted because he had ample responsibilities to be done. The community and his followers failed to make him stay; they prepared for provision during his journey instead. They made food for him such as chicken, duck, snacks, ketupat, side dishes, young coconut leaves, and so on. They escorted Datu Milir to a place where he said, "We meet up to here now. Come here all the baik baluk toker goneng (Sasak expression for descendants)". Having said that, Datu Milir stuck his stick to the ground and disappeared. Suddenly, water spurted from the ground where Datu Milir stuck his stick. This place then was called ' $A i$ ' Lingsar" or Lingsar water. All Lingsar people and his followers put the provision they brought such as chicken, ketupat, duck, and snacks in the place where the water spurted. From then, Lingsar people have performed a ceremony to respect Datu/Wali Milir annually. The

\footnotetext{
${ }^{17}$ Hindus regard this temple (Pura Ulon) as a place of worshiping to a number of gods (dewa), particularly Dewa Gunung Rinjani and Dewa Gunung Agung. See Edy Sdyawati, et al., "Integrasi antar Etnik Berbeda Agama Melalui Upacara Agama, Kajian Tentang Hubungan antar Etnik Bali dan Etnik Sasak Melalui Upacara Perang Topat di Pura Lingsar Lombok Barat" (n.p: 1998), p. 78.

18 The custodian of Kemalik is hereditarily assigned to a family of Datu Sumilir's descendants. The first Kemalik custodian was Nuralam and then transmitted to his son and descendants. The followings are the custodians of Kemalik consecutively: 1). Nuraalam, 2). Nurtalam, 3). Indrawan, 4). Amak Lingsari, 5). Nurawan, 6). Syamsiyah, 7). Sanusi, 8). Rahmat Asmin, and 9). Suparman Taufiq. When Indrawan was in charge of the third custodian of Kemalik, Gaduh Temple and Ulon Temple were built next to Kemalik.

${ }^{19}$ In the local folklore, it is stated that the original name of Datu Milir or Sumilir is Haji Abdul Malik or Wali Raden Mas Kertajagat, an Islamic preacher from Java.
} 
ceremony is called puja wali, literally meaning a prayer for a saint. Muslims observe the puja wali ritual and Hindus perform the odalan ritual at the same time and on the same site.

Before the ceremony, both Balinese-Hindus and Sasak-Muslims clean the Lingsar Temple area and repair the broken roofs. The SasakMuslims usually clean the Kemalik area, and some of them clean the Ulon Temple, while the Balinese-Hindus clean the whole temple area. They use brooms, mattocks, and sickles. Holy water is sprayed on all those tools to purify them. A pemangku leads the purification of the ritual utensils in the Muslim community while a pedanda (Balinese traditional leader) leads the cleaning in the Hindu community. ${ }^{20}$ Two days before the puja wali ceremony and perang topat, the two communities of Balinese-Hindus and Sasak-Muslims set abah-abah or ider-ider (all utensils applied in the tradition such as banners, flags, umbrellas, spears, and so on in Gaduh Temple, Ulon Temple, and Kemalik). The cooperation and mutual assistance described above are the manifestation of a harmonious relationship between Hindus and Muslims. The Lombok society and government have perpetuated such peaceful relation. The government of West Lombok has made efforts to maintain and develop the tradition as a part of the tourism publiccation.

In recent years, the Culture and Tourism Agency of West Lombok have held various activities regarding the perang topat ceremony. Last year, the agency conducted al-syafa'ah recitation at night before the perang topat. Muslims held the al-syafaah recitation by reading al-Ikhlas (a chapter in the Qur'an) 1000 times. ${ }^{21}$ Last year, as a series of puja wali and perang topat festival, the local committee held several performances in Lingsar such as a puppet show, presean, Sasak traditional performing arts and others. This event took place on November 24-26, 2015.

During the perang topat festival, the organizing committee sets a canvas shelter and stage for dance performances. Under a 100 square meter canvas shelter, the government officials such as the West

20 For the explanation about pedandas and tuan gurus in dealing with conflict, see Suprapto, "The Theology of Tolerance in Hindu and Islam: Maintaining Social Integration in Lombok-Indonesia," Ulumuna 19, no. 2 (2016): pp. 329-352. See also Suprapto, "Religious Leaders and Peacebuilding: The Role of Tuan Guru and Pedanda in Conflict Resolution in Lombok-Indonesia," Al-Jami'ab: Journal of Islamic Studies 53, no. 1 (2015), pp. 225-250.

${ }^{21}$ http://antaramataram.com/berita/?rubrik=8\&id=13707 accessed on September 15, 2015. 
Lombok Regent, the head of West Lombok police department, the head of West Lombok military department, religious leaders, and community leaders sit together to watch traditional performances while ordinary people stand around the stage. After the puja wali ceremony, perang topat takes place. Before the fight, ketupat in all sizes from the smallest one as big as an egg to the biggest one as big as an adult are brought in a procession to Kemalik. The Sasak traditional music, kendang belek, and some traditional guards called batek baris accompany the procession. The guards usually wear the colonial Dutch military costumes. The betek baris walk in the front row followed by women bringing ketupat, offering flowers, and fruits.

It is interesting to observe women's appearances. Some wear headscarves, and some do not. Their religious identities can be identified easily from their appearances. Women wearing headscarves are Muslims while the others are Hindus. After saying prayers for the ketupat and all offerings in Kemalik at approximately $17.00 \mathrm{pm}$ Lombok time or at rara' kembang waru (the time when waru flowers fall), people do the fight and throw the ketupat to each other. The battle ends when the sun is down and all ketupat run out.

\section{The Contestation of Meanings for the Perang Topat Site and Utensils}

The participation of two different ethno-religious communities in one ritual rarely occurs especially when it takes place in one location. Both communities have a particular motivation and belief that encourage them to voluntarily and even compulsorily perform the ritual annually. It is essential to elaborate their conceptions about specific matters such as the tradition itself, site, and its symbolic meanings to understand views of the ceremony participants deeply. The community's loyalty in having the festival is based on a particular belief. According to Koentjaraningrat, a ritual system remains perpetuated when its participants have a notion of time, place, materials, and ritual leaders. The difference in the ritual participants' religions results in various conceptions and understandings.

The Balinese-Hindu community and the Sasak-Muslim community possess different notions about several buildings in the Lingsar Temple area. For instance, some Sasak-Muslims interpret 17 stairs in Gaduh Temple, which bridge the temple with Kemalik, as a symbol of the Qur'an revelation on the $17^{\text {th }}$ Ramadhan. The number 17 also 
represents the number of rakaat (essential unit of prayer ritual which consists of bows and prostrations performed a prescribed number of times) in daily five times prayers. In the perang topat festival, the master of ceremony usually explains such meanings of symbols of the buildings in Lingsar Temple. It is interesting to explore deeper that such Muslims' interpretation of the 17 stairs bridging Gaduh Temple and Kemalik as the date of the Qur'an revelation and the number of rakaat in daily five times prayers is a recent interpretation from the Wetu Telu community that has accepted Waktu Lima teachings.

The Hindu community pays attention to the Balinese-Hindu's architecture of the temple.22 They interpret the water fountains in Kemalik within the Balinese-Hindu's perspective. According to the Hindus, the water fountain is a symbol of eight points of wind directions. However, the Muslims perceive that the number of the fountains is not eight but nine, which symbolizes the number of Walisongo (nine Muslim preachers) who spread Islam in Java.

The various conceptions deriving from different beliefs and traditions imply three meanings. First, the different notions suggest conflict in the temple's property possession. Second, there has been the negotiation of meanings about the temple based on their beliefs and religions. Third, the diverse interpretations of the sacred buildings in Lingsar Temple motivate the two different communities and particularly Sasak-Muslims to perpetuate the perang topat ritual in the temple. For Hindus, performing prayer in the temple is their common religious tradition. For Muslims, their conceptions of the buildings in Lingsar Temple demonstrate their respect for their ancestors' legacy. The Muslims prefer appealing the building as "Lingsar Garden" instead of "Lingsar Temple" while the Hindus prefer the latter designation. The term "garden" illustrates a more cultural meaning than the word "temple," which designates a more religious nuance.

The diversity in conceptions of culture is common. Cultural symbols have always been contested and negotiated by many people with different interests. According to Irwan Abdullah, "Symbols and their meanings are the objects of interpretation that involves contestants who have different interests." 23 Therefore, meanings of a

\footnotetext{
22 Sdyawati, "Integrasi, p. 86.

${ }^{23}$ Irwan Abdullah, Kontruksi dan Reproduksi Kebudayaan (Yogyakarta: Pustaka Pelajar, 2006), p. 5.
} 
symbol may vary depending on the sake of the Balinese-Hindu community and the Sasak-Muslim community, which changes according to time and conditions. In other words, the meaning reconstruction of cultural products such as cultural materials applied in the perang topat tradition always occurs.

As a hereditary tradition from generation to generation involving thousands of people, perang topat requires many cultural materials such as rombong, offerings, kebun odek, lamak, momot, a buffalo, and ketupat. The negotiation in the interpretation of those cultural elements appears as described in the followings.

Rombong is a small shed containing sticky rice and offerings. The shed symbolizes prosperity and social welfare. The offerings are put in nine dulang (Sasak traditional trays) with rice. Rice in the trays represents soil fertility and people's prosperity. The rombong manifests gratitude to God for His blessings regarding abundant foodstuff.

Kebun odek or a small garden is made from old green coconuts. The tips of the coconuts are cut and stuck by nine 20 and 30 centimeters culms of bamboos, which are set in a crisscross order. Various fruits are placed in that mini garden. Kebon odek denotes soil fertility benefiting for people's prosperity.

Lamak or a mat is made from pandan leaves. Interestingly, utensils used in Islamic prayers such as a prayer mat, sarong, a special prayer cloth for Muslim males, and a prayer cap for men, and a special prayer cloth for females are put inside a rolled mat. Sogan-sogan (a square box from plaited bamboo) is placed over the rolled mat. Al-Qur'an is stored inside the box. The lamak and sogan-sogan reveal a meaning that Muslims have to observe daily five times prayers and read Qur'an.

Momot is one liter-sized bottle, which is empty, closed, sealed, wrapped in a white fabric, and tied tightly. The bottle implies a meaning that humans will experience an eternal mysterious life (closed) in the hereafter.

A buffalo is also taken to surround Lingsar Temple. A buffalo delineates the provision brought by Syekh Kiai H. Abdul Malik when he preached in Lingsar and nearby areas. The buffalo is then slaughtered, cooked, and served for Balinese-Hindus and SasakMuslims, who make the trail surrounding the temple. A selection of a buffalo instead of a cow or a pig has a particular meaning. The selection is a win-win solution for both different communities. A pig is forbidden for Muslims while a cow is sacred for Hindus. 
The most important tool in perang topat tradition is ketupat applied in a battle. There are thousands of ketupat. The number of the ketupat should be a multiplication of nine, which symbolizes the history of Walisongo. Walisongo, which means nine Muslim saints, were the first preachers who spread Islam in Java.

Sasak-Muslims and Balinese-Hindus believe that the ketupat contains a blessing because it is prayed before being used for fighting. The people bring the leftover ketupat home and spread it in their rice fields at night while they say a prayer to ask God to bless them with soil fertility and abundant harvest. Lalu Lukman, a Lingsar resident who always participates in the perang topat tradition every year, said, "I will hang this ketupat on trees so that they will result in plenty fruits. I also spread the ketupat in my rice fields to get the good harvest." 24 The leftover ketupat is also believed to increase the harvest in freshwater farming. The people put the ketupat in their fishponds and fish cages along a river in the village.

The construction of meanings for symbols is crucial for Muslims. Their understanding of the site, utensils, and rituals of perang topat influences their participation in it. According to Suparman Taufik, the ninth custodian of Kemalik, it is important to provide an Islamic explanation of perang topat. For instance, Taufik interprets the number of water fountains, pancor siwak/the nine fountains. Nine is a sacred number. According to Taufik, the sacredness of number nine for Islam is reflected on the followings:

(1) the 99 God's beautiful names (asma al-husna); (2) Ramadhan (the month of fasting) is the ninth month of the Islamic lunar calendar (Qamariyah calendar system); (3) the haij (pilgrimage) starts on the ninth of Dzul Hijjah; (4) the Wali Songo or the nine Javanese Islamic preachers who successfully converted the Javanese majority into Islam; (5) God creation of nine holes on human's body: two ears, two eyes, two nose trills, one mouth/throat, one genital, and one anus; (6) Any number multiplied by nine, and the result of such multiplication when they are added will return to nine. For example, $9 \times 73=657,6+5+7=18,1+8=9) .{ }^{25}$

\footnotetext{
${ }^{24}$ Interview with Lalu Lukman, a Muslim participant from Gerung, West Lombok on November 26, 2015.

${ }^{25}$ Budiwanti, "Balinese Minority, p. 244.
} 
Through the explanation above, Taufik emphasized that the Muslims' involvement in the traditions and Islamic observance in Lingsar Temple and Garden does not contradict Islamic teachings. Taufik refuted the criticism from the puritan Muslims, who view prayers performed in Kemalik as syirik, idolatry or polytheism i.e. the deification or worship of anyone or anything other than Allah. Taufik asserted that performing prayers in Kemalik is not syirik because Muslims pray to Allah directly through their prophets and saints, not praying or asking help or blessing to saints. Taufik said, "In fact, Muslims coming to Kemalik must possess tawhid (the belief in God as the One and Single) and read qul buwa Allabu abad (God is One). This recitation is called bekulub in Sasak tradition. So, we ask Allah."26

\section{The Negotiation of Meanings and Civic Engagement}

The diversity in the communities' conceptions of the perang topat site and its tools has not discouraged them from its performance every year. The conception difference occurs only among the leaders of both communities of Balinese-Hindus and Sasak-Muslims while the ordinary people have a lack of understanding about the meanings of the perang topat site and utensils. Essentially, interpretation on the implications of perang topat tradition indicates the negotiation between Hindu and Islamic beliefs. Perang topat as a symbol of a peaceful relationship between Sasak-Muslims and Balinese-Hindus prevails.

The Sasak-Muslim community involved in perang topat acknowledges that the tradition has bound them with their fellows from the Balinese ethnic group that devote to Hinduism. Inak Nuriyah, who lives near Lingsar Temple, said, "We have lived together and built families in Lingsar for years. We have not had conflict. We have helped each other from generation to generation." Similarly, I Made Sukarta, a Balinese, said that Lombok is his homeland, and he considers his Sasak neighbors as his semeton (relatives). This practice is the embodiment of civic engagement involving two different ethnoreligious communities. Referring to Putnam, such good relationship is categorized into a bridging network as a universal symbol.

Symbols of harmony between the Muslim community and the Hindu community manifest in the perang topat tradition are parallel to their peaceful relationship in their daily lives. The communities in

${ }^{26}$ Interview with Suparman Taufik, November 9-10, 2016. 
Lingsar and Lombok live in harmony and peace. Some tensions and conflicts happening in recent years in Lombok $^{27}$ have not changed their orientation toward harmony and peace in Lingsar. The communities' relation has been established towards integration and harmony instead of conflict. The people in Lingsar have provided assistance to each other and done reciprocal invitations and visits when a member of the community holds a feast (begawe). They also usually deliver food to each other. When a member of the community passes away, the other people come to his or her funeral. Such activities have existed as living traditions in the daily life of Balinese-Hindus and Sasak-Muslims.

The living traditions described above are the norms of remarkable reciprocity among members of the communities. According to Putnam, ${ }^{28}$ the reciprocity norms are one element of social capital in addition to other two elements: interpersonal trust and civic engagement. The existence of those three elements of social capital proves to have persevered solidarity and cohesiveness of society in Lingsar.

Interpersonal trust among members of a community leads to awareness of providing assistance to each other. Helping a neighbor, who is having a feast (begawe/rowab), is a common tradition in Lingsar society. In several events such as having a newborn baby, wedding, funeral, and other religious festivals such as maulid nabi (the Prophet Muhammad's birthday) and isra wa al-mi'raj (the Prophet Muhammad's journey to the heavens), a community member usually prepares a lot of food and invites his or her neighbors, friends, and relatives to enjoy the feast. They sit with their legs crossed in a circle and enjoy the prepared meals together (begibung/megibung). In a begibung, all people sit

\footnotetext{
${ }^{27}$ Over the last 10 years, several conflicts occurred in Lombok, in which most of them occured outside the Lingsar village, such as the conflict among villagers of Karang Genteng and Petemon and Karang Jasi and Karang Tapen, social unrest on January 17, 2000, and the attacks and expulsion of Salafi groups and the Ahmadiyah. See Khamami Zada, et al., Prakarsa Perdamaian: Pengalaman dari Berbagai Konflik Sosial (Jakarta: Penerbit Lakpesdam NU, 2008), pp. 89-95; Fawaizul Umam, "Menolak Kekerasan, Menenggang Keragaman: Refleksi atas Kasus Kekerasan terhadap Ahmadiyah," Jurnal Tasamub Vol 4, No. 1 (December 2006): pp. 25-38. See also Suprapto, Semerbak Dupa di Pulau Seribu Masjid: Kontestasi, Integrasi dan Resolusi Konflik. Hindu-Islam (Jakarta: Prenada Kencana, 2013).

${ }^{28}$ Robert D. Putnam, Making Democracy Work. Civic Tradition in Modern Italy (Princeton: Princenton University Press, 1993), p. 167.
} 
equally regardless of their social status. They socialize in an atmosphere of a big family. Even though the community leaders, religious leaders, and traditional chiefs are usually served first then other community members, their positions in begibung are equal. They eat with hands (muluk in the Javanese language). They enjoy the same meals while they are having conversation openly. This tradition portrays harmony among people in the community. The spirit of silaturabim (kinship) appears strongly in such activity.

The rowah practice in Lombok resembles the slametan tradition in the Javanese community. ${ }^{29}$ Rowah or slametan is held to celebrate several cycles of life. Regarding funeral, for instance, several feasts are held to send prayers to a dead person on the third day (nelung), the seventh day (mitu), the ninth day (nyiwa), the fortieth day (metang dasa), the hundredth day (nyatus), the five hundredth day (nanun), the nine hundredth day (nyangga), and the one-thousandth day (nyiu) after his or her funeral. Nowadays, people usually hold feasts for commemorating a dead person only until the hundredth day after his or her funeral..$^{30}$

The kinship model manifest in mutual assistance does not appear only within the Muslims but also between diverse religious groups. The people help each other by providing foodstuff and cooking. Male members of the community bring coconuts and peel them in the house of the feast host. They also carry other utensils required for the feast. Female members of the community help voluntarily in cooking and serving meals. The members of the community treat all people equally including a newcomer. Mutual helping occurs due to mutual trust among people.

The civic engagement within the society in Lingsar and other regions in Lombok can be observed from several pekraman (association). The Sasak community and the Balinese community have established several krama such as krama banjar (an organization involving people from several kampongs), krama gubuk (an association involving people within a kampong), and krama desa (an association at the village level). Krama or an association is established based on the

29 Marwan Sholahuddin, "Mengenal Kearifan Lokal di Klepu Ponorogo: Praktik Hubungan Sosial Lintas Agama dan Mekanisme Pencegahan Konflik," in Irwan Abdullah, et al. (eds), Agama dan Kearifan Lokal dalam Tantangan Global (Yogyakarta: Pustaka Pelajar, 2008), pp. 13-48.

30 Faizah, Dakwah Salafiyah di Lombok; Suatu Kajian Komunikasi antar Budaya (Unpublished Ph.D Dissertation, UIN Syarif Hidayatullah Jakarta, 2010), p. 146. 
same interest of its members. For instance, within krama banjar, there are krama banjar subak (an association of farmers and peasants), krama banjar merariq (an association of young people for wedding preparation), krama banjar mate (an association for helping a funeral), krama banjar haji (an association for helping a member of community who is going to perform a pilgrimage), and krama pura (an organization for maintaining a Hindu temple). ${ }^{31}$

Those living traditions in the society of Lingsar and all areas in Lombok built on mutual trust, reciprocity norms, and networks (pekraman) have been perpetuated up to now. They have been maintained through daily social interactions and annual cultural events such as perang topat. However, a further question arises about whether or not traditions like perang topat can be preserved along with today changes and advances. What are challenges in culture preservation? How do local elites develop the tradition?

\section{The Prospects and Challenges in the Development of Perang Topat}

Perang topat has been an annual tradition held from generation to generation. The culture has been performed and maintained since 1759. Furthermore, the local government of West Lombok has made perang topat as an annual tourism agenda to attract domestic and foreign tourists to visit Lombok.

The local government has a keen interest in developing the perang topat tradition. Mahrif, the Former Deputy Regent of West Lombok, said that the perang topat tradition contains three functions: theological, sociological, and economic. Theologically, the perang topat ceremony and its series of activities are an expression of gratitude for all blessings from God the Almighty. Sociologically, the perang topat tradition is a symbol of social integration between diverse ethnicities and religions particularly Balinese-Hindus and Sasak-Muslims. In the economic perspective, the annual tradition of perang topat attracts domestic and foreign tourists to visit Lombok if it is performed remarkably. Therefore, in the next years, the government of West Lombok will create additional activities such as a performance of kendang belek (a Sasak traditional music) to the perang topat tradition to make it more

31 David D Harnish, Bridges to The Ancestors: Music, Myth, and Cultural Politics at an Indonesian Festival (Hawaii: University of Hawaii Press, 2006), p. 97. 
attractive. ${ }^{32}$ Furthermore, the government of West Lombok has just built several amenities such as an art shop, food courts, and a convenient and wide parking area in Lingsar Temple.

Considering the perang topat functions and the Lombok society's spirit, it seems that the tradition will be more developed in the future. Varied motivations and interests of the Lombok people regarding the tradition do not hamper the performance of perang topat but encourage more creativity and innovation.

Some challenges to the perang topat tradition comes from Muslim puritans, who consider it violating Islamic teachings. They view Muslims' participation in a temple, which is a Hindus' praying place, is forbidden in Islam. Muslims' involvement in a ritual of Hindu temple is seen as the preservation of Wetu Telu Islam teaching. Some Muslim preachers coming from outside of Mataram City often criticize Muslims' engagement in the perang topat festival and other Hindu cultural events such as the ogoh-ogoh (statues built in the forms of mythological beings, mostly demons, representing evil spirits) parade before the Nyepi day (the biggest religious festival for Hindus).

Regarding such resistance and criticism from Muslim puritans, the participants of the perang topat tradition have stated that what they do is a cultural activity. Their participation in perang topat only manifests a tradition of respecting the legacy from Sasak ancestors. Cultural motifs in the perang topat tradition are more apparent than religious ones. Muslims' participation in the perang topat tradition does not associate with a religious belief. Similarly, Muslims' involvement in the ogoh-ogoh parade before the Nyepi day celebrated by Hindus is merely cultural. They watch the show as a cultural event. Syardan, a resident of Karang Baru who watched the ogoh-ogoh parade with his son last year, said, "We look at the show. We do not follow the religion of Hinduism. We watch ogoh-ogoh. We do not observe Nyepi." 33

Muslims' engagement in an event held by people from different religious background has been a sensitive issue, but not vice versa. Non-Muslims involve in Muslims' festivals voluntarily, but not vice versa. Muslims are not always deliberate to engage in a celebration of another religion. In July and August 2016, many non-Muslims

32 http://antaramataram.com/berita/?rubrik=8\&id=13707 accessed on February 12, 2016.

${ }^{33}$ Interview with Syardan on April 22, 2015. 
provided assistance in the 26th Musabaqob Tilawatil Qur'an Nasional (MTQN/The National Competition of the Qur'an Recitation). ${ }^{34}$ For example, some Christian leaders participated in the opening parade held two days before the MTQN. Similarly, according to the Governor of West Nusa Tenggara Province as the head of the MTQN organizing committee, the Confucianism adherents from Chinese ethnicity were also involved in the MTQN by putting lampions on the main venues of the MTQN. Besides, the pecalang (Hindu safeguards) assisted the police department actively in keeping safety in several MTQN areas and helped the MTQN participants coming from different provinces in Indonesia find hotels and inns. Conversely, when people from various religions hold a national event in Lombok, the Muslim community does not always engage in it. Therefore, such unequal relationship between the Muslim community and other religious communities cannot be categorized as civic engagement based on reciprocity norms.

Another challenge in the perang topat tradition comes from young people. Recently, some youths have participated in the topat fight by throwing decayed eggs and tomatoes instead of ketupat, which have engendered inconvenience for the others hit by the rotten food. Police officers from Lingsar sub-district and Narmada sub-district have been deployed to pacify those youths. Besides, another activity that potentially disturbs intercommunity harmony is the tradition of sabung ayam (cockfight) held several days before perang topat. Sabung ayam or sabuh rub is a cockfight perceived as a part of the perang topat ritual. It is said that the Sasak ancestors who spread religion in Lingsar liked a cockfight. Nonetheless, in recent years, the cockfight has urged its spectators to play gambling or betting. Such deviance in the perang topat tradition may diminish the solemnity of the ceremony and destroy the meanings of puja wali and perang topat traditions.

\section{Conclusion}

On the basis of above analysis, it can be summed up that the perang topat tradition appears to remain preserved by both communities from

\footnotetext{
${ }^{34}$ For more details on this, see "Dukung MTQ di NTB, Warga Tionghoa Sumbang Lampion dan Pecalang Bantu Amankan Lokasi” in http://regional.kompas.com/read/2016/07/31/08523941/. See also "Anshor, Pramuka, sampai Pecalang Siap Sukseskan MTQN Mataram” in https://www.kemenag.go.id/berita/384802/anshorpramuka-sampai-pecalang-siap-sukseskan-mtqn-mataram accessed on August 3, 2016.
} 
diverse ethnicities and religions: Balinese-Hindus and Sasak-Muslims. The tradition can be designated as "one ceremony for two religions." The meanings of the perang topat site, utensils, and rituals have been constructed continuously in accordance with socio-religious-political changes in the society.

In the mid of new pressures and criticism from so-called reformist groups particularly puritanist Muslims, the Lingsar Muslim community has faced harder challenges than the Hindu community. For Hindus, the participation in the perang topat festival is a part of their religious ritual and thus it is not problematic. For Muslims, their involvement in the perang topat tradition requires justification based on Islamic concepts. What Suparman Taufik, the Kemalik custodian, did in constructing meanings of the perang topat site, utensils, and rituals, can be viewed as a negotiation strategy for several arguments. First, that is a legitimation for Muslims to perform perang topat as a religious ritual. Second, the Lingsar Muslim community maintains and respects their cultural heritage trough such meaning construction. Third, they preserve a harmonious relation with both other Muslim groups and the Hindu community. Therefore, the Lingsar Muslim community develops civic engagement continuously as well as perpetuates the perang topat tradition. The Lingsar Muslim community's efforts can be seen as strategies in peacebuilding among diverse ethno-religious communities. Besides, the government presence in making the perang topat tradition as an annual cultural event is an additional strategy in perpetuating the tradition.]

\section{References}

\section{Books and Articles}

Abdullah, Irwan. Simbol, Makna dan Pandangan Hidup Jawa: Analisis Gunungan pada Upacara Grebeg. Yogyakarta: Balai Kajian Sejarah dan Nilai Tradisional, 2002.

--------. Kontruksi dan Reproduksi Kebudayaan. Yogyakarta: Pustaka Pelajar, 2006.

Arzaki, Djalaludin et al. Nilai-Nilai Agama dan Kearifan Budaya Lokal Suku Bangsa Sasak dalam Pluralisme Kebidupan Masyarakat. Mataram: Pokja Redam NTB, 2001.

Bartholomew, John Ryan. Alif Lam Mim Kearifan Masyarakat Sasak 
trans. Imron Rasyidi. Yogyakarta: Tiara Wacana, 2001.

Bowie, Fiona. The Anthropology of Religion: An Introduction. Massachusetts: Blackwell Publisher, 2001.

Budiwanti, Erni. Islam Sasak: Wetu Telu versus Waktu Lima. Yogyakarta: LKiS, 2000.

-. "Balinese Minority Versus Sasak Majority: Managing Ethno-

Religious Diversity and Disputes in Western Lombok." Heritage of Nusantara: International Journal of Religious Literature and Heritage 3, no. 2 (2015): pp. 233-250.

Cederroth, Sven. The Spell of The Ancestors and The Power of Mekekah, A Sasak Community on Lombok. Goteborg: Acta Universitatis Gothoburgensis, 1981.

---------. A Sacred Cloth Religion?: Ceremonies of the Big Feast Among the Wetu Telu Sasak (Lombok, Indonesia). Copenhagen, Denmark: NIAS Book, 1999.

Coppel, CA. ed. Violent Conflicts in Indonesia: Analysis, Representation, Resolution. London: Routledge, 2005.

Faizah. Dakwah Salafiyah di Lombok; Suatu Kajian Komunikasi antar Budaya. Unpubilshed Ph.D Dissertation, UIN Syarif Hidayatullah Jakarta, 2010.

Gaborieau, Marc. "Konflik Hindu Muslim di India dalam Perspektif Sejarah" in Dewi Fortuna Anwar, Helene Bouvier, Glen Smith, and Roger Tol (eds). Konflik Kekerasan Internal: Tinjauan Sejarah, Ekonomi Politik dan Kebijakan di Asia Pasifik, Trans. Masri Maris. Jakarta: Yayasan Obor Indonesia, 2004.

Geertz, Clifford. Local Knowledge: Further Essays in Interpretative Anthropology. New York: Basic Books, 1983.

Harnish, David D. Bridges to The Ancestors: Music, Myth, and Cultural Politics at an Indonesian Festival. Hawaii: University of Hawaii Press, 2006.

-------. "Balinese and Sasak Religious Trajectories in Lombok." Between Harmony and Discrimination: Negotiating Religious Identities within Majority-Minority Relationships in Bali and Lombok. Brill, 2014.

Koentjaraningrat. "Asas-asas Ritus, Upacara dan Religi” in 
Koentjaraningrat (ed.). Ritus Peraliban di Indonesia. Jakarta: Balai Pustaka, 1985.

Pranowo, M. Bambang. Memahami Islam Jawa. Jakarta: Pustaka Alvabet, 2011.

Robinson, Francis. "Islam and Modern Society in South Asia." Contribution to Indian Sociology 17 (2): pp. 185 - 203.

Ramsbotham, Oliver, Tom Woodhouse and Hugh Mial. Contemporary Conflict Resolution. The Prevention, Management and Transformation of Deadly Conflicts. Cambridge: Polity Press, 2006.

Saifuddin, Ahmad Fedyani. Antropologi Kontemporer: Suatu Pengantar Kritis Mengenai Paradigma. Jakarta: Kencana, 2006.

Salmi, Ralph H., Cesar Adib Majul, and George Kilpatrick Tanham. Islam and Conflict Resolution: Theories and Practices. University Press of America, 1998.

Sdyawati, Edy et al. "Integrasi antar Etnik Berbeda Agama Melalui Upacara Agama, Kajian Tentang Hubungan antar Etnik Bali dan Etnik Sasak Melalui Upacara Perang Topat di Pura Lingsar Lombok Barat", A research report, the Ministry of Education and Culture, the Directorate of Culture, History, and Traditional Values, the Project of Research and Development of Balinese Culture, 1998.

Sholahuddin, Marwan. "Mengenal Kearifan Lokal di Klepu Ponorogo: Praktik Hubungan Sosial Lintas Agama dan Mekanisme Pencegahan Konflik." Irwan Abdullah, et al. (eds). Agama dan Kearifan Lokal dalam Tantangan Global. Yogyakarta: Pustaka Pelajar, 2008.

Suprapto. Semerbak Dupa di Pulau Seribu Masjid: Kontestasi, Integrasi dan Resolusi Konflik Hindu-Islam. Jakarta: Prenada Kencana, 2013.

-------. 'Taqāīìd 'Harb' Topat: Ramz al-'Alāqah al-Silmīyah bayn alJamā 'àt al-Mukhtalifah 'Ariqìyā wa-Dīnīyā fì Jazīrat Lombok." Studia Islamika 18, no. 3 (2014).

--------. "The Theology Of Tolerance In Hindu And Islam: Maintaining Social Integration In Lombok-Indonesia." Ulumuna 19, no. 2 (2016): pp. 329-352. -. "Religious Leaders And Peace Building: The Role of Tuan Guru and Pedanda in Conflict Resolution in Lombok- 
Indonesia." Al-Jami'ab: Journal of Islamic Studies 53, no. 1 (2015): pp. 225-250.

Telle, Kari. "Spirited places and ritual dynamics among Sasak Muslims on Lombok." Anthropological Forum, vol. 19, no. 3 (2009): pp. 289-306.

Umam, Fawaizul. "Menolak Kekerasan, Menenggang Keragaman: Refleksi atas Kasus Kekerasan terhadap Ahmadiyah.” Jurnal Tasamub Vol 4, No. 1 December (2006): pp. 25-38.

van der Kran, Alfons. Lombok: Conquest, Colonialization and Underdevelopment, 1870-1940. Singapore: Heinemann Educational Books, 1980.

van Klinken, Gerry. Communal Violence and Democratization in Indonesia: Small Town Wars. London: Routledge, 2007.

Varhsney, Ashutosh. Ethnic Conflict and Civic Life: Hindus and Muslims in India. New Haven and London: Yale University Press, 2002.

Wirata, I Wayan. "Inter-Cultural Communication between Local Hindu and Islamic Community in Perang Topat Ceremony in Lingsar Temple, Narmada District, Lombok." History 5, no. 13 (2015): pp. 7-10.

Zada, Khamami et al. Prakarsa Perdamaian: Pengalaman dari Berbagai Konflik Sosial. Jakarta: Penerbit Lakpesdam NU, 2008.

\section{Electronic Sources}

http:/ / antaramataram.com/berita $/$ ?rubrik $=8 \&$ id $=13707$

http://lombokbaratkab.go.id/.

http://regional.kompas.com/read/2016/07/31/08523941/

http://regional.kompas.com/read/2016/07/31/08523941/.

https://www.kemenag.go.id/berita/384802/anshor-pramuka-sampaipecalang-siap-sukseskan-mtqn-mataram 